\title{
PJIEE
}

Premise: Journal of English Education and Applied Linguistics

https://fkip.ummetro.ac.id/journal/index.php/english

Turmudi and Hajan

\section{EDUCATION SYSTEM AND ENGLISH LANGUAGE TEACHING IN THE PHILIPPINES: IMPLICATIONS FOR INDONESIAN EFL LEARNING}

\author{
Dedi Turmudi \\ Universitas Negeri Malang, Indonesia \\ Home-based: Universitas Muhammadiyah Metro, Indonesia \\ tdeditur@gmail.com \\ Bonjovi Hassan Hajan \\ José Rizal University, the Philippines \\ bonjovihajan36@gmail.com
}

Received: February 25, 2020

Revised: March 20, 2020

Abstract:

The Philippines is held as one of the largest English-speaking countries worldwide with most of its people possessing at least some degree of fluency in the target language. The prestige of the English language in this country has attracted the attention of many foreign students including Indonesian. In this paper, we aimed to discuss the education system and the English language teaching (ELT) in the Philippines so that practical insights can be gained to reflect on Indonesian EFL learning. To this end, we first described how the Philippine education system looks like and how the English language is taught in schools from elementary to tertiary level. We then explored some prevailing challenges surrounding the ELT, and established links relating the benefits of learning English in this country to Indonesian EFL context. Drawing on qualitative approach, we realized our research objectives by carefully selecting sources and data through critical review of articles from journals, books, websites, and other reliable sources retrieved online. Ultimately, we conducted this inquiry to find out answers so that some lessons learned can be adopted to make ELT in Indonesia better and more resilient since Indonesia remains left behind in the spectrum of English literacy.

Keywords; education, Philippines, English, ELT

\section{INTRODUCTION}

The Philippine Human Index Development (IHD) gets better from year to year, which began from 118 in 2012 to 115 in 2014 with 0.67 index. This improvement is supported with the status of English as a second language (ESL) even though some people ascribe to the Philippines as a "semi English-speaking country" (Ozaki, 2011). According to Cabigon (2015), the Philippines is heralded as one of the biggest English-speaking countries worldwide with most 
of its people possessing at least some degree of fluency in the target language. This is not a question since English in the Philippines has been used as a lingua franca due to the country's rich linguistic diversity (Wa-Mbaleka, 2014). As a lingua franca, English is one of the official languages of the Philippines aside from Filipino, the national language and is spoken by more than 14 million Filipinos (Cabigon, 2015). It is the language of business and law, as well as the principal medium of instruction in education from primary to tertiary education (Cabigon, 2015).

The implementation of English language education was promoted in the Philippines when Spain was defeated by the US in 1889, and since then, English has become the common medium of communication (Bernado, 2006, as cited in, Ozaki, 2011). This suggests that English can be spoken and understood well if the people are exposed to both spoken and written discourses. Meanwhile, Martin (2014) notes that "among ASEAN countries, the Philippines occupies a unique position in that English was brought to the country by the Americans, rather than the British. Three hundred years of Spanish occupation did do anything to make the Spanish language occupy the same prestige status that English enjoys today" (p. 475). Such statements clearly indicate that the development of English language in the Philippines has continued to thrive and prosper.

Consequently, several reasons can be considered as to why the Philippine Education System and English Language Teaching (ELT) in particular should be taken into account for Indonesian learners. Perhaps, among the most practical one is the tuition rate which is comparatively lower than that of ten overseas universities (MANAGEMENT, 2015). Another viable reason could be thorough exposure to the English-speaking environment in schools. A student, for example, does not need to take an additional English course since almost all subjects are taught in English accompanied by English textbooks. Such practice can also be observed in Singaporean Education System (SES). However, the cost of education in Singapore is more expensive for the Indonesian learners who are from the middle class or lower family (Chandra, 2015).

Given such vantage point, we discuss in this paper several facets of Philippine education specifically focusing on its system, the English as a second language, the challenges of teaching and learning English as a second language, and the benefits of learning the English language in the Philippines. In so doing, we hope to illuminate practical insights central for the development 
of English language teaching in Indonesia. More importantly, through this paper, we sharpen and broaden our expertise in the area of ELT, and thus by analyzing the system of education and how English is taught, we hope to make a positive contribution to the education system in Indonesia.

Hence, we first describe the education system in the Philippines and its ELT context and then attempt to relate its applications for Indonesian EFL learners. Specifically, we aim to answer the following research questions:

1. What does the education system in the Philippines look like?

2. How is English taught in schools?

3. What are the challenges of teaching and learning English as a second language?

4. What are the benefits of learning English in the Philippines for Indonesian EFL?

\section{RESEARCH METHOD}

\section{Research Design}

In the study, we adopted a descriptive qualitative research. Specifically, we performed critical literature review meant to shape a conceptual paper (Turmudi, 2020). The contents were qualitative data to enrich the statement as planned in the research objectives, and thus no statistical calculation was applied (Heigham \& Croker, 2009).

\section{Data Collection and Analysis}

We retrieved synchronously the supporting data synchronously from many sources based on the needs of answering the objectives of the study. The data covered articles from journals, books, websites, and other reliable sources. We digested, cited and arranged in the list of references the associate sources. We then arranged the reference list using word reference manager (Turmudi, 2020).

Since this paper is purely descriptive in nature relying on published materials, we followed methodical steps to support the writing process and to ensure the validity and reliability of the data to be processed. These steps are described in the following procedures. 
1. Proposing a topic to write

2. Making research objectives

3. Finding articles through internet access based on keywords related to the topic under study

4. Reading the downloaded articles

5. Annotating read articles and writing initial analysis based on the research objectives

6. Outlining the full article's structure

7. Writing supporting arguments integrating literature reviewed, citing the sources intext and listing the cited arguments in the list of reference using word reference manager

8. Editing the manuscript and checking the in-text citation and reference list

We had carefully undertaken all of these steps to support the further process of data analysis and to ensure the rigor of the paper.

\section{RESULTS AND DISCUSSION}

\section{What does the education system in the Philippines look like?}

Like other countries in the world, the Philippine government has put serious attention to its educational development aiming to make every citizen prosperous and humanistic. This attempt is clearly stated in the state laws. Article 14 of the constitution stipulates that the school shall inculcate patriotism and nationalism, foster love for humanity, respect for human rights appreciation of the rule of national heroes in the historical development of the country, teach the rights and duties of citizenship, strengthen ethical and spiritual values, develop moral character and personal discipline, encourage critical and creative thinking, broaden science and technological knowledge, and promote vocational efficiency.

As deeply entrenched in the central goal of the Philippine education for all 2015 National Action Plan prepared in 2006, the structure of education in the Philippines covers basic competencies that promote functional literacy for all. The vision of every Filipino family is to ensure that each son or daughter has the opportunity of high-quality education that will make him or her a whole person leading him or her to become a productive or a successful 
entrepreneur ( PTFE, 2008, as cited in WDE, 2011). This vivid grant and attempt to make a real human life of the Filipinos is the real concern of the government to serve every individual whose nationality is Filipino.

Apart from this concern, the Philippine government also grants and promotes English as its second language so that every individual gets the best goal of his or her life. The government further designs a comprehensive schema of the education structure as a complete process of how education is carried and provided since pre-education until post-graduate education. This schematic diagram shows ages, length of time and the degree to which a student can go beyond his or her education.

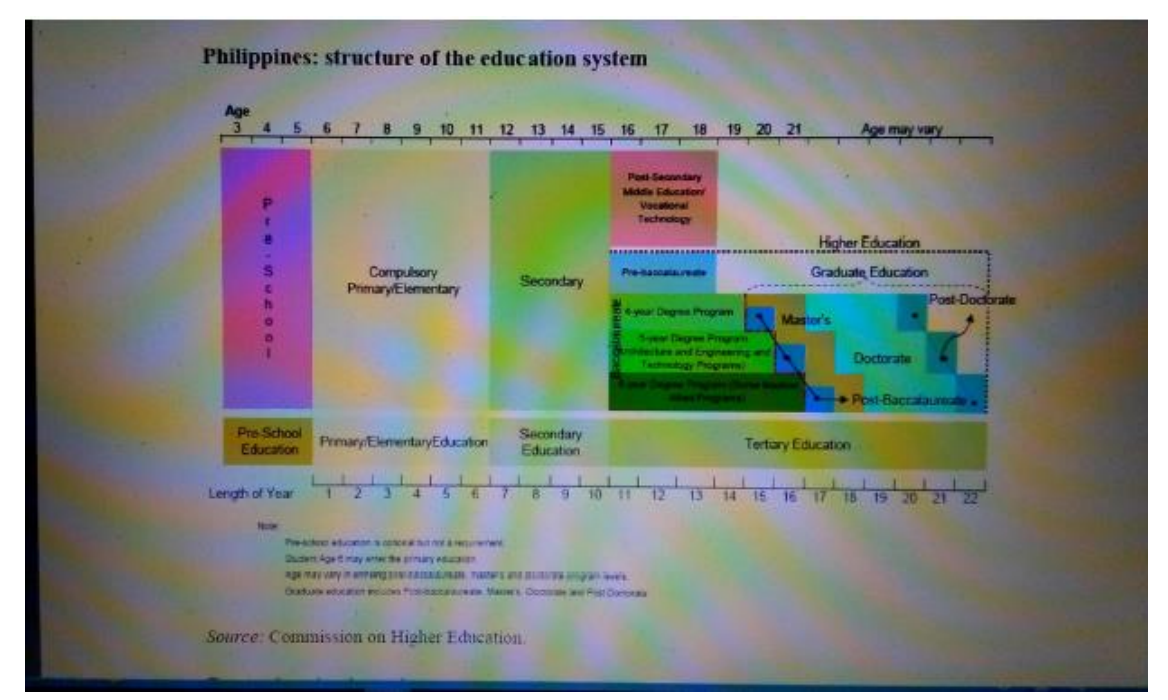

Figure 1. Structure of the Philippine Education System (UNESCO, 2011)

Since 1935 to 1987, English was the only language of instruction in schools. However, due to a mandate of the new constitution both English and Filipino are assured to be the official languages of instruction and communication. In reality, beyond that regulation, English is almost always the spoken language in learning after primary school, especially in the urban and the State Universities and Colleges (SUCs) in the country. This means that the Filipino education system introduces English as the medium of instruction since pre-school until university. This process gradually makes every single learner acquire English as a second language despite the interference of Filipino language, which is the national language. Unlike in Indonesia in which English is taught in schools since elementary and in certain majors such as English Department, in the Philippines, students learn all subjects in English and with 
English as instructional language as well (Cabigon, 2015). The summary of how English is leant and spoken can be described below.

Table 1

Table of School Grades and Stages in Philippines Education System (CANADA, 2004)

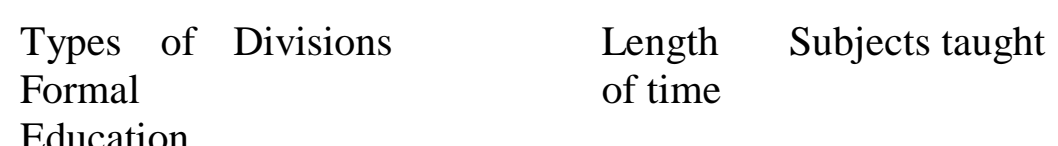

Education

$\begin{array}{ll}\text { Primary Cycle I } 4 & \begin{array}{l}\text { Language Arts (Pilipino, English and Local } \\ \text { Dialect) Mathematics Health Science civics } \\ \text { and culture }\end{array}\end{array}$

Primary Cycle 22 Language Arts (Pilipino, English and Local Dialect) Mathematics Health Science civics and culture. music and art; physical education; home economics and livelihood; and social studies

General Secondary 4 School communicative arts (English and Pilipino), mathematics, science, technology, and social sciences, physical education, music, and citizen army training), home economics, agriculture and fisheries, industrial arts and entrepreneurship), values education and some electives, including subjects from both academic and vocational pathways.

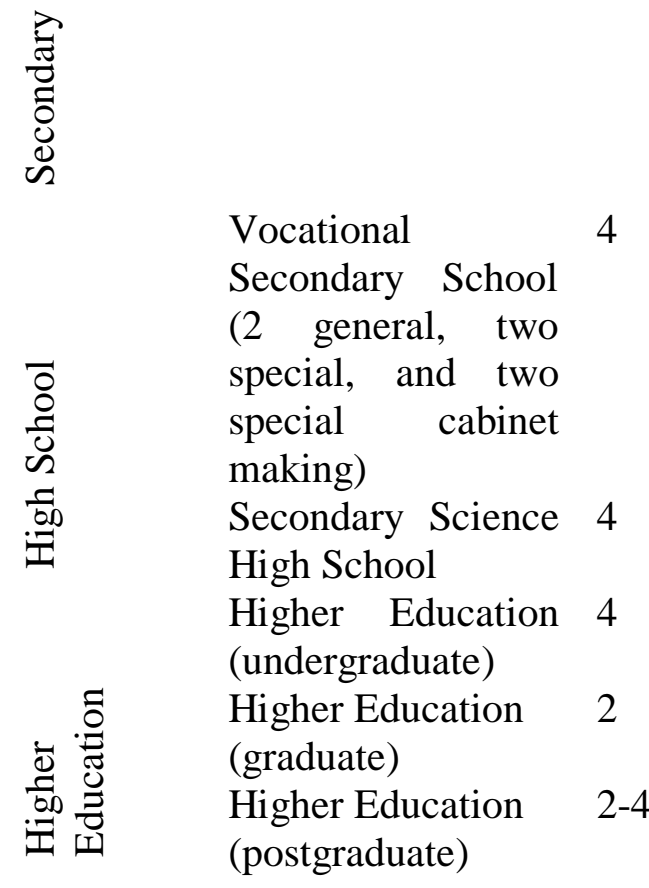

five major fields: agriculture, fishery, trade/technical, home industry, and nontraditional courses with a host of specializations.

the pure and applied sciences, mathematics, or engineering upon entering college.

Specialise in any field leading to operator

Specialise in any field leading to developer

Specialize in any field leading to a creator

This summary shows that the education system and English language teaching in the Philippines are different from that of the education system and English language teaching in Indonesia. 


\section{How is English taught in schools?}

In general, English is taught in all level of schools from elementary to tertiary. This stage is segmented into several phases and episodes and along with the development of this country after gaining full independence on July 4, 1946. Although Emilio Aguinaldo proclaimed Philippine independence from the Spanish regime on June 12, 1898, Filipinos had never been freed by Americans until the US signed the Treaty of Manila on July 4, 1946, granting that the Philippines gained "full independence" from the United States of America. Consequently, Spanish was not widely used in the education system but the English language (SE, n.d.). The Philippines, however, celebrates Independence Day (or Araw ng Kalayaan) every June 12 to commemorate their freedom from Spain. In the further essay, how English taught will be explained in some sub-topic seen from history and types of English instruction at schools in this country.

Martin (2014) summarized critical points on how English is taught among Filipinos. English was introduced in the Filipino classroom by American soldiers who first taught in Corregaridor in 1898. Since then, English was made as a medium of instruction (MOI) in all levels. Along with the colonization (1898-1946) for fifty years, English was promoted in the classrooms as if it were a native language for Filipino speakers (p.475).

The form of how this model was massively implemented at Philippine schools was found to be written in one of the American principals in 2011 as seen in his diary expressed below.

"We must insist that every day in his first three years of school life, the Filipino child has a dialogue lesson, and we must make him commit that lesson absolutely to memory.

For instance, suppose his first lesson is as brief as this: Good morning, Pedro. Good morning, Jose. How are you this morning, Pedro? Thank you. I am very well. It would not be cruelty to animals to insist on any second-grade pupil's committing that lesson to memory"(Martin, 2002, as cited in, Martin, 2014, p. 476).

This is the indication of how and to what extent English was English during the colonization. In more comprehensive outlines, English was instructed as in the following description. First, the students are asked to do dialogue memorization (Audio Lingual Method). Further, they are also trained to do activities in the classroom such as stressing eye movements 
in reading, asking students to read aloud, making them perform grammar drills, and expecting them to recite memorized passages. All of these activities are identified as techniques in the Audio-Lingual Method (ALM) invented by Fries and developed by B.F. Skinner (Encyclopedia, n.d.).

Simultaneously, the government is in support of how English is learnt and spoken through a systematic program called Mother-Tongue-Based Multilingual Education (MTBMLE) law. The Philippines passed the MTB-MLE law recently, which requires earlier grades to be taught in students' mother tongues (Wa-Mbaleka, 2014). This is seen in the statements below.

"Under the MTB-MLE law, the number of English instruction periods is highly limited.

From the Input Hypothesis perspective, it can be expected that the English learning process will be slower as a result of MTB-MLE. This law is good for learning in general. Its application, however, is causing some challenges because it is still new, and it looks like limited training has been provided to teachers, in this Outer Circle country" (p.71).

Research shows that the Philippines is successful in the teaching and learning of English. The evidence of this success is seen through the promotion of English through the media, home, school, tourism, business, and even the sending of English teachers abroad. Some surveys even proved that the Philippines was the best non-native English-speaking country in business English. A significantly high percentage of people in the Philippines speak English as compared to the neighboring countries (Wa-Mbaleka, 2014).

\section{The curriculum of English for Secondary School}

As this paper goes beyond the fact that English is spoken and written language, the government through Departement of Secondary Education in the Philippines has designed the English curriculum for students to learn along their school time. In general, students are exposed to English atmosphere in both indoor (teaching-learning process) and outdoor (communicating with people daily). In particular, the Filipino government regulates English as described in the program called Conceptual Framework of the English Program (Education, 2010). Overall, the schematic diagram is detailed below:

Premise Journal Vo. 9 No 1, April 2020, e-ISSN: 2442-482x, p-ISSN: 2089-3345, page 78-93 Copyright@2020 by PJEE 


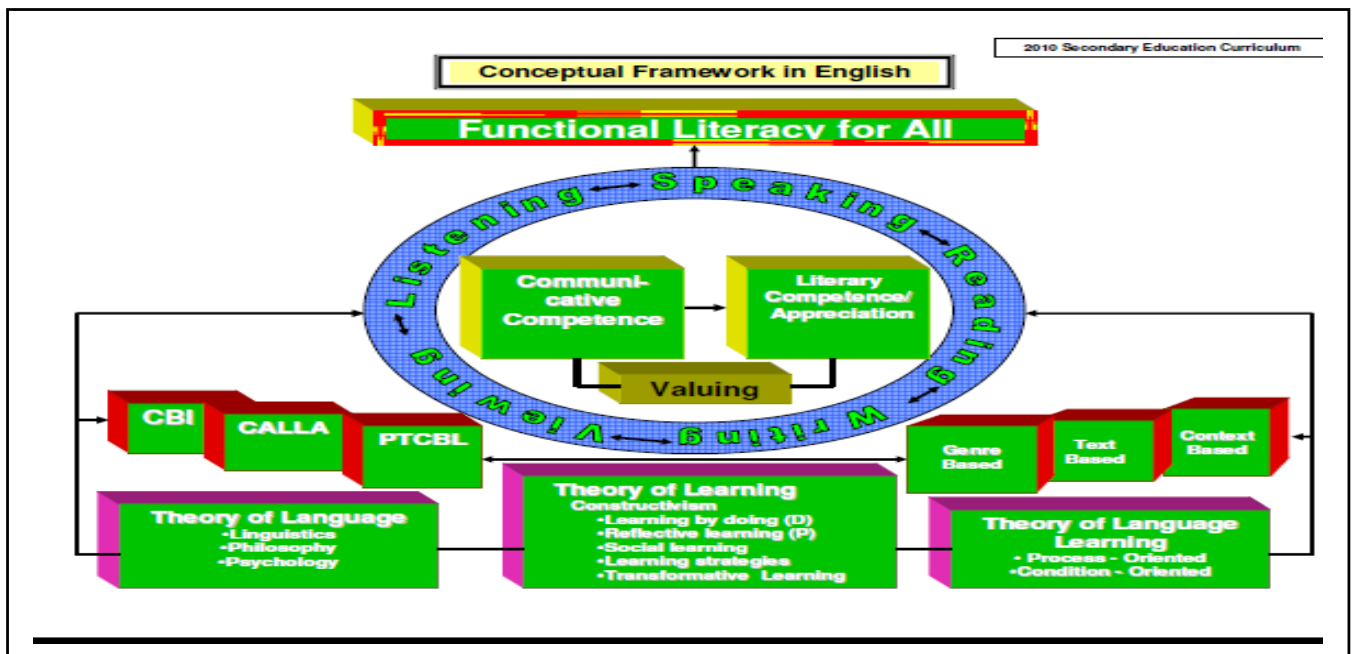

Figure 2. Conceptual Framework of the English Program in the Philippines (Education, 2010)

The overall goal of the 2010 Secondary Education Curriculum of English is to develop a functional literate Filipino who can effectively function in various communication situations. It underlies critical competencies comprising of the ability to express clearly ideas and feelings orally, in writing, and non-verbally, to learn on his own, to read, comprehend and respond in turn to ideas presented (Education, 2010).

The two-fold goals of this program are to develop the English communicative, and literary competence/appreciation of the Filipino youth ended with four competencies: linguistic, sociolinguistic, discourse and strategic with emphasis on cognitive academic language proficiency (CALP). The macro language skills such listening, reading, speaking and writing are equipped with providing facilities to view multimedia and internet source information as the means to develop creativity in encoding essential information during studying(Education, 210).

\section{How English is taught in Elementary Schools}

The ministry of tourism of the Philippines (2014) reports (as cited in, Rubiyantoro, 2015) that $93.5 \%$ of Filipinos can speak English fluently. This success can be traced back to how People use English as their communication tool and how English is exposed to Filipinos in daily life. In particular, English is taught since elementary school until universities in more intense portion than that in Indonesia. 
In Elementary school (ES), Grade I students learn English for five months, and in Grade II, students study English for 12 months. Since Grade III, all subjects of science are integrated into the English language. The subjects are called MAPEH (Music, Art, Physical Education, and Health), and the other subjects such mathematics, Tagalog language, social science and GMRC (Good Manners and Right Conduct) are in English.

In grade IV of ES, students get additional courses called HELE (Home Economics and Livelihood Education). All of these subjects are taught and written in English. This continues until high school in that all subjects related to sciences are instructed and written in English. This final assessment is also measured in English (Rubiyantoro, 2015). Such structure also works for the university level.

It is not surprising that English achievement of internet-based test (iBT) of Filipino is higher and reached 88 off 120 averagely reported and taken from 2008-2012. The average TOEFL iBT score of Filipino people was 88 out of 120 taken between January and December 2008, which ranked number two in Asia. This figure is very high compared to 66 for the Japanese (ETS, 2009, p.10). Indonesian average score in iBT, however; was 78 (ETS, 2009).

\section{How English is taught in Secondary Schools}

English is shown at a critical period of learning that is teenager episode in the Philippines. The government regulates English to be taught through a well-planned curriculum, which is called the 2010 Secondary Education Curriculum: Curriculum Guide in English. In stage I, this curriculum regulates desired outcomes of learning, essential understanding, essential questions (content standards and performance standards). In the second stage, it rules assessment and product performance. In phase III, it guides the learning plan in which instructional activities that students will pass through to gain the standards (Education, 2010).

\section{English in Tertiary Education or Higher Education}

As the Filipinos have sufficient achievement of English learning through many subjects and courses, tertiary education in the Philippines fully uses English as a medium of instruction and communication. The bilingual education come to a halt at secondary school and to some specific courses called GMRC covers Filipino, civics and culture, good manners and right conduct (character education), home economics, livelihood education, music, art and physical education are taught in Filipino. At secondary, only 1 social studies values education, physical 
education, health and music are taught in Filipino (Education, 2010). Further education upper than secondary uses fully English except major in Filipino and foreign languages.

\section{What are the challenges of teaching English as a second language?}

Amid this successful story of how Filipinos acquire English proficiency, challenges arise in this country. Nevertheless, the discussion with respect to this area addresses overall and general obstacles due to limited data sources. It is interesting to note that the Philippines comprises of more than 180 ethnic languages and dialects. In connection to this, Wa-Mbaleka (2014, p.73) notes a number of challenges facing the teaching English in the Philippines. First, while MTB-MLE is a law that is based on sound linguistic theory of learning, its ineffective implementation can lead to catastrophic results in the teaching and learning of English. Second, time allocated to the teaching and learning of English in the new $\mathrm{K}$ to 12 program is not enough for effective learning of a new language. Last, the lack of ESOL materials and TESOL experts could be seen as a threat to the sustainability of English language teaching and learning in the Philippines. This implies that despite English being one of the official languages, obstacles abound the teaching context since the learners have different mother tongues as their first language and Filipino as their first official language.

In addition, Ozaki (2011) highlighted his findings stating that:

Filipino English has distinctive features in terms of grammar, pronunciation, and vocabulary (refer to Trudgill \& Hannah, 1994, for details). Due to such distinctive features, some people might consider Filipino English to be nonstandard. However, teachers in the Philippines use Standard English, although this statement is not based on any systematic research but rather solely on my impression (p. 57).

Further, some challenge may also arise as pertaining to mentioned below:

The fact that Filipino host family members are likely to speak (a) language(s) other than

English to each other. Consequently, there is a fear that the amount of input at home might be insufficient for students. However, this problem can be solved if host families agree to speak only English while they are with the students (Ozaki, 2011).

Considering this situation, it is of no question that there is not any single English program without obstacle yet the English language is embedded and integrated not only as the 
language of subjects or courses but more importantly as the language of materials and instructions in the education system.

\section{What are the benefits of learning English in the Philippines for Indonesian EFL?}

In Indonesia, English language learners continue to face challenges when it comes to communicating in the target language because their first language is more widely used in daily communications and English is treated only as a foreign language. In the Philippines, however; Indonesian learners may not find this drawback. It is logical that the Filipinos will not use their mother tongue since English is used as one of the official languages and that they have the pride to be as an English-speaking nation. In addition, it makes sense that they will use English since Filipino as the national language may not be understood by all ethnic groups due to ethnolinguistic diversity. Thus, we argue that learning English in the Philippines is roughly better than that in Indonesia due to several reasons.

Ozaki (2011) highlighted his knowledge and positive things that a learner will get in learning English in the Philippines. He notes that the main benefits include the following. First, the cost of learning is cheaper than any other country like European countries, Australia and America, Singapore and Japan. Second, Indonesian people are alike in the skin, posture, and facial pattern with that of Filipinos. These physical traits may promote a close relationship in learning and up to the level of convenience. Third, Filipino English teachers have characteristics that enable them to help foreigners either native or non-native speakers in the way they develop their English ability. Fourth, students can experience using English as lingua franca when talking to any Filipinos. Finally, a highly advanced learner can significantly benefit from involving in an English language program in the Philippines as they offer both English program for those international students and those for Filipinos (p. 54-55). All of these may work for Indonesian learners and can be better as Indonesian does not have a past time conflict with Filipinos.

A further probe might be worth emphasizing to reflect on the lessons learned about Indonesia. What we digested from the literature reviews can be surmised in the following highlights. First, English is taught as subject matter from primary school to university. Consequently, students will strongly have the foundation of the four skills including syntax and lexicon. Second, English is integrated into Science subjects or sourcebooks. As a result, they 
will get used to understanding the target language through content-based learning sources. This will scaffold the further development of language acquisition of learners since they need more content-related language as they move to higher education. Third, English is used in the interaction of teaching and learning process. Such practice could enable students to develop their speaking skill into a native-like proficiency. Finally, English is used as a medium of communication in public space; therefore, students will have contextual spoken English as supporting learning atmosphere. It might be limited to student-teacher interaction, studentofficial communication, and official meetings and events among the public. All of these can be selectively replicated in Indonesia to adjust the Indonesian English literacy rate on behalf of emphasizing English language mastery.

\section{CONCLUSION}

In this paper, we attempted to discuss the education system and English language teaching in the Philippines. Specifically, we illustrated how the Philippine education system looks like and how English language is taught in schools from elementary to higher education. We further uncovered some challenges surrounding the teaching and learning of English as a second language in the Philippines. From these discussions, we established links relating the benefits of learning English in the Philippines to Indonesian EFL.

By describing the ELT in the Philippines in this study, we can conclude that, while the Indonesia and the Philippines are categorized as the developing countries in Asia as based on their Index Human Development (IHD), the atmosphere of learning English in the Philippines is better because the potential chance to speak L1 language of Indonesian can be absent as they get used to speaking in English both in classroom interaction with teachers and with people outside in real life such as in business correspondence. Moreover, although the Philippines Education System (PES) might not be better than Indonesian Education System (IES) in the sense of time duration at primary and secondary levels, it is worth documenting how English language is fostered and sustained from primary to tertiary level in the Philippines. With this, we can assume that English language teaching in the Philippines is much better than it is in Indonesia. The indicators can easily be traced back to the outcome of the iBT TOEFL test, which was number 2 in Asia (Ozaki, 2011) and the widely used English in public views of Filipinos. 
Based on our conclusions, we recommend Indonesian students to study English in the Philippines if they cannot go to any English-speaking countries such as US, Australia, New Zealand, and England for certain reasons such budget and scholarship rejection. Thus, learning English in the Philippines can be said to be the least among the best yet the best among the most expensive in the world.

\section{BIO-PROFILE}

Dedi Turmudi was a former head of English Department and a senior English lecturer at Muhammadiyah University of Metro Lampung Indonesia. He received his Master Degree from the SIT Graduate Institute or previously known for the School for International Training (SIT) Brattleboro, Vermont USA with ESOL as his minor concentration. He had filed up his experience at high school for 12 years and has published a number of books and presented research articles at International Conferences since 2009. He specializes his lecturing at writing and teaching methodologies. However; his main research is in writing development and intercultural communication for language teachers (ICLT/CCU). He is a postgraduate student at Universitas Negeri Malang specializes in ELT program. Corresponding email: tdeditur@gmail.com ORCID ID ; http://orcid.org/0000-0003-4803-5854

\section{BIO-PROFILE}

Bonjovi Hassan Hajan is a Research Faculty at the Senior High School Division in José Rizal University, Philippines. He is a M.A.Ed in English Language Teaching (ELT) candidate at the Philippine Normal University. He is a fellow at International Association of Scholars, Educators, Researchers and Practitioners (I-ASERP) and a teacher trainer at Asian Center of Education, Research and Training for Innovation (ACERT). Bonjovi also serves as a senior editor and a peer reviewer in reputable academic journals. His research publications explore the different areas of ELT including second language teaching and learning, teacher cognition, blended learning, academic writing, and discourse analysis 


\section{REFERENCES}

Cabigon, M. (2015). State of English in the Philippines: Should we be concerned? British Council, Philippines. Retrieved from https://www.britishcouncil.ph/teach/state-englishphilippines-should-we-be-concerned-2

CANADA, W. E. (2004, 5 30). Education overview in the Philippines. Retrieved 9 29, 2016, from https://www.wes.org/: https://www.wes.org/ca/wedb/philippines/rpedov.htm

Chandra, I. (2015, June 26). Perbandingan biaya kuliah luar negeri di 6 negara. Retrieved October 28, 2016, from http://www.kompasiana.com/isabellachandra/perbandinganbiaya-kuliah-luar-negeri-di-6-negara-infografis_5501897aa33311376f5138e7

Education, D. O. (2010). 2010 Secondary education curriculum: Curriculum guide in English. Pasing: Curriculum Development Division.

Encyclopedia, W. t. (n.d.). Audio-lingual_method. Retrieved 9 29, 206, from https://en.wikipedia.org/: https://en.wikipedia.org/wiki/Audio-lingual_method

English Testing Service (ETS). (2009). Test and score data summary for TOEFL internet-based and paper-based tests: January 2008 - December 2008 test data. Retrieved March 13, 2010 from http://www.ets.org/Media/Tests/TOEFL/pdf/test_score_data_summ ary_2008.pdf

Heigham, J., \& Croker, R. A. (2009). Qualitative research in applied linguistics: A practical introduction. (J. H. Croker, Ed.) London: Palgrave Macmillan UK. doi:https://doi.org/10.1057/978023023951

MANAGEMENT, E. B. (2015). Biaya kuliah dan biaya hidup per tahun di Filipina . Retrieved October 28, 2016, from http://edubless.co.id/: http://edubless.co.id/wpcontent/uploads/2016/02/PERBANDINGAN-BIAYA-KULIAH-LUAR-NEGERI.pdf

Martin, I. F. (2014). English langauge teaching in the Philippines. World Englishes, 33(4), $472-$ 485. Retrieved from https://www.academia.edu/

Ozaki, S. (2011). Learning English as an international lingua franca in a semi-English-speaking country: The Philippines. The Asian EFL Journal, 53, 51-60. Retrieved September 29, 2016, from http://www.asian-efl-journal.com

Rubiyantoro, Y. (2015, Agustus 12). Beginilah cara pelajar Filipina bahasa Inggris. Retrieved $929, \quad 2016, \quad$ from http://www.kompasiana.com/: http://www.kompasiana.com/yohanrubiyantoro/beginilah-cara-pelajar-filipina-belajarbahasa-inggris_55ca8222c022bd2f10d794cf

SE (n.d.). Education system in Philippines. Retrieved 9 29, 2016, from http://www.studycountry.com/guide/PH-education.htm:

Turmudi, D. (2020). English scholarly publishing activities in the industrial revolution 4.0: what, why, and how? English Language Teaching Educational Journal, 3(1), 52-63. ELTEJ, 3(1), 52-63. Retrieved May 1, 2020, from http://journal2.uad.ac.id/index.php/eltej/article/view/1890 
UNESCO. (2011). World data on Education. New York: International Bureou of Education. Retrieved 10 5, 2016

Wa-Mbaleka, S. (2014). Teaching English to speakers of other langauges: The case of Philippines. International Journal of Academic Research in Progressive Education and Development, 3(3), 64-78. doi:10.6007/IJARPED/v3-i3/952 